\title{
Forensic investigation of two Christian and Muslim mass graves skeletal remains in Sorya, Duhok governorate, Iraqi Kurdistan
}

\begin{abstract}
Background and objective: This study aimed to investigate two mass graves located in Sorya village, Duhok governorate-Iraqi Kurdistan region.

Methods: The investigation included excavation of the graves and identification of the victims. The field study was started after taking testimonies and witnesses for locating the site of graves. Two sites were described (Site 001 and site 002), which were excavated according to the scientific standard procedures. Sex determination, age, and stature estimation were performed on the remained skeletons in the medico-legal institute-Erbil laboratory.
\end{abstract}

Results: Site 001 included 14 bodies, two of them were males and five were females, whereas the others were not identified because of degradations happens to the bones. Site 002 included 25 bodies, which were Christians according to witnesses and supported by evidence. Four victims appeared to be males, 14 were females, and 7 could not be identified. The results of age estimation reported that the number of young bodies in site 001 was five bodies, which represent $35.7 \%$ of them all, while 13 out of 25 were young bodies in site 002 , which produced $52 \%$ of all victims. All the remained bones were recorded in detail for more documentation.

Conclusion: This finding described the exhumation and anthropological evaluation of two mass graves in Sorya- Duhok governorate Iraqi Kurdistan region. The majority of the victims were females and contain Christian and Muslims people.

Keywords: Mass graves; Christian victims; Sorya village; Anthropological identification.

\section{Introduction}

Throughout modern history, Christians have been geographically dispersed, with large numbers in cities across Iraq. In 1961 there were one million Christians in northern Iraq. ${ }^{1}$ However, by $1979,50 \%$ of Christians were living in Baghdad, making up $14 \%$ of the capital's population. ${ }^{2}$ Under the Ba'ath regime's Arabisation policies, the community was required to identify as either Arab or Kurd in the 1977 census. $^{3}$ Now, the largely reduced Christian population remains in Baghdad, Basra, Kirkuk, the Nineveh Plains, as well as the Erbil and Duhok governorates in the Kurdistan regional government. ${ }^{4}$ The last Iraqi census, in 1987, counted 1.4 million Christians, but the economic sanctions during the 1990s led to their migration abroad. Before starting the Gulf War between Iraq and Coalition forces in 1991, they were estimated at about one million. By the time of the US-led invasion in 2003, that figure fell to about 800,000 . Then the numbers are thought to have fallen dramatically after attacking them by different groups of terrorist especially in Nineveh. ${ }^{5}$ The identification of mass graves skeletal remains and anthropological evaluation considered as the most important step toward documenting human rights violations which lead to giving back to families the remaining skeleton of victims, which are considered, until exhumed, as lost or disappeared. ${ }^{3}$ The mass graves in Iraq are

${ }^{1}$ Medical Research Center, Hawler Medical University, Erbil, Iraq

2 Department of Medical Lab. Technology, Health Technical College, Erbil, Iraq.

* Correspondence: dr_yka@yahoo.com 
identified as unmarked sites containing at least six bodies. Some can be characterized as deep pits that appear to have been filled or by mounds of earth piled above the ground, but older mass graves are difficult to found because over this long period, they have been covered by debris and vegetation. ${ }^{6}$ Various mass graves have been identified in almost all regions of Iraq that contain people of different religious and ethnic groups as well as foreign nationals, including Arabs such as Kuwaitis and Saudis. ${ }^{1}$ The Iraqi government estimates that there are 250000 to a million missing people, according to the International Commission on Missing Persons (ICMP). However, some estimates put the number of missing from Saddam's attacks, including attacks against the Kurds in the 1980s and 1990s, at more than 1 million. Therefore, the Kurdish people say "There is another Iraq, buried under Iraq". ${ }^{2}$ This paper's main intention is to present and discuss the exhumation, anthropological evaluation, and individual victim identification of two mass graves in Sorya village, Duhok governorate, Iraqi Kurdistan region.

\section{Methods}

\section{Testimonies and witnesses for locating} the graves sites

Despite the emotional influences on the witnesses' statements, they were still the most important and reliable source of information for general or specific site

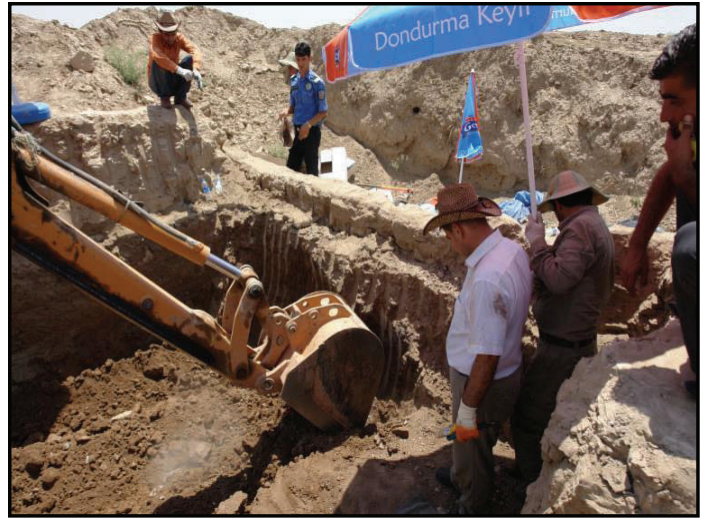

locations of the two graves. In this study, we depend on the witness's statements, which they were victims saved from the killing.

\section{Site Description and Assessment}

Before the excavation took place, a preliminary visit to the suspected site was made to map the area to be excavated. Above all, we ensured that the area had been cleared of surface debris. The graves sites were in Sorya village, located on the old road between Duhok city and the countryside of Zakho. We found two mass grave sites (site 001 and site 002). The two mass grave sites were in different locations, near each other for about 50 meters, and they were different in their sizes. The first site appeared to be smaller and contains less number of bodies.

\section{Excavation}

After identifying the two gravesites' location, the major dimensions (width, length, and depth) were estimated as closely as possible. The ground's surface was examined for finding any important evidence such as bullets, jewelry, personal belongings, etc.) before being slowly and carefully removed. Soil removal was then probed by careful use of picks and shovel and finally, with trowels and brushes. For site 002, which contained Christian people killed during the repression of 1969, we first broke the stony wall made by the Christian people for 42 years ago to recognize the place.

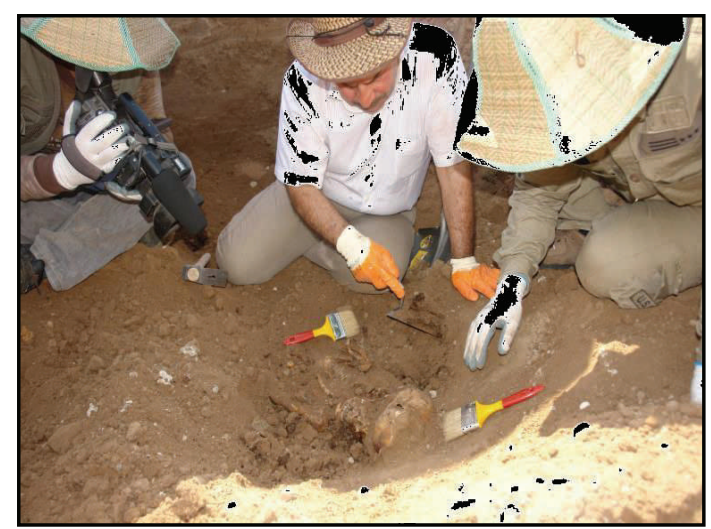

Figure 1: The excavation and exhumation processes in two mass graves in Sorya village, Duhok governorate, Iraqi Kurdistan region. 


\section{Osteological Analysis}

The osteological analysis is concerned with determining the identity of a skeleton by estimating its age, sex, and stature. A count of the 'minimum number of individuals' (MNI) was performed as a standard procedure in osteological reports on inhumations to confirm how many individuals are present by the articulated and disarticulated human bones. The MNI was calculated by counting all long bone ends, and other larger skeletal elements recovered. The $\mathrm{MNI}$ was considered as the largest number of these skeletons. The MNI is mostly lesser than the actual number of skeletons which have been interred on the site, but it can represent the scientifically proven minimum number of individuals in the graves. ${ }^{7}$ The osteological analysis is concerned with the determination of the identity of a skeleton by estimating its age, sex, and stature. Age was determined using standard aging techniques. ${ }^{8}$ Age estimation relies on the presence of the pelvis and uses different stages of bone development and degeneration to calculate the age of an individual. Age is split into two categories: Young victims include the ages below 18 years old, and adult victims, including the ages equal or more than 18 years old. Sex determination was carried out using standard osteological techniques, such as those described by Mays.9 Assessment of sex in both males and females relies on preserving the skull and the pelvis and can only be carried out once sexual characteristics have developed, during late puberty and early adulthood. Stature was estimated by applying the formulae for the maximum length of femur developed using modern Portuguese samples. ${ }^{10}$

\section{Data analysis}

Microsoft Excel program was applied for summarizing and graphical presentation of the data. Percent values were calculated as a descriptive statistical analysis for the acquired data.

\section{Results}

The victim's bodies then transferred to Erbil city, the Iraqi-Kurdistan region's capital city, where they stored in the morgue of the Kurdistan Medico-legal Institute. The laboratory works were done in special laboratories of the medico-legal institute for estimation of Age, Sex, and stature after the bodies have been separated and the skeleton outline finished. All the works had been done by a special team who had taken a training course in the ICMP program. The results are shown in Tables 1 and 2 . Using a special form prepared by ICMP, we recorded the presented and absent bones for everybody as much as possible. This work was challenging and needed too much hard work, as most of the bones had degenerated. For determination of sex, we tried to determine all, but some bodies were not appropriated for that determination, especially the bodies of mass grave site 001 . 
Table 1: Site 001 detailed information including presented bones, age, and stature.

\begin{tabular}{|c|c|c|c|c|c|c|c|c|c|c|c|}
\hline $\begin{array}{l}\text { Case } \\
\text { No. }\end{array}$ & $\begin{array}{l}\text { Structure } \\
(\mathrm{cm})\end{array}$ & Age & Cranial & facial & Mandible & vertebrae & $\begin{array}{l}\text { Upper } \\
\text { limb: } \\
\mathbf{R}\end{array}$ & $\begin{array}{c}\text { Upper } \\
\text { Limp: } \\
\text { L }\end{array}$ & Pelvis & $\begin{array}{l}\text { Upper } \\
\text { limb: } \\
\mathbf{R}\end{array}$ & $\begin{array}{c}\text { Lower } \\
\text { Limb: } \\
\text { L }\end{array}$ \\
\hline M1 & $\mathrm{NI}$ & 34 & $\mathrm{NI}$ & $\mathrm{NI}$ & $\mathrm{NI}$ & 3 & 0 & 1 & $\mathrm{NI}$ & 3 & 2 \\
\hline M2 & $\mathrm{NI}$ & N.A & $\mathrm{NI}$ & $\mathrm{NI}$ & Av. & 4 & 3 & 0 & Av. & 0 & 0 \\
\hline M3 & $\mathrm{NI}$ & N.A & Av. & Av. & Av. & 0 & 0 & 0 & $\mathrm{NI}$ & 0 & 0 \\
\hline M4 & 156 & 15 & $\mathrm{NI}$ & $\mathrm{NI}$ & Av. & 0 & 0 & 3 & $\mathrm{NI}$ & 0 & 0 \\
\hline M5 & $\mathrm{NI}$ & N.A & Av. & $\mathrm{NI}$ & $\mathrm{NI}$ & 0 & 1 & 0 & $\mathrm{NI}$ & 0 & 0 \\
\hline M6 & 157 & 16 & $\mathrm{NI}$ & $\mathrm{NI}$ & $\mathrm{NI}$ & 5 & 0 & 0 & Av. & 1 & 2 \\
\hline M7 & 157 & 13 & Av. & Av. & Av. & 0 & 2 & 0 & $\mathrm{NI}$ & 0 & 0 \\
\hline M8 & 171 & 17 & Av. & Av. & Av. & 11 & 2 & 3 & $\mathrm{NI}$ & 0 & 0 \\
\hline M9 & $\mathrm{NI}$ & N.A & $\mathrm{NI}$ & $\mathrm{NI}$ & $\mathrm{NI}$ & 0 & 0 & 0 & $\mathrm{NI}$ & 0 & 0 \\
\hline M10 & $\mathrm{NI}$ & N.A & $\mathrm{NI}$ & $\mathrm{NI}$ & $\mathrm{NI}$ & 14 & 0 & 0 & $\mathrm{NI}$ & 0 & 0 \\
\hline M11 & $\mathrm{NI}$ & N.A & $\mathrm{NI}$ & $\mathrm{NI}$ & $\mathrm{NI}$ & 10 & 0 & 0 & Av. & 0 & 0 \\
\hline M12 & $\mathrm{NI}$ & N.A & Av. & Av. & Av. & 5 & 4 & 1 & Av. & 0 & 0 \\
\hline M13 & $\mathrm{NI}$ & N.A & $\mathrm{NI}$ & $\mathrm{NI}$ & $\mathrm{NI}$ & 3 & 1 & 2 & Av. & 0 & 0 \\
\hline M14 & 170 & 16 & $\mathrm{NI}$ & $\mathrm{NI}$ & $\mathrm{NI}$ & 22 & 4 & 5 & Av. & 1 & 1 \\
\hline
\end{tabular}

Table 2: Site 002 detailed information including presented bones, age and stature.

\begin{tabular}{|c|c|c|c|c|c|c|c|c|c|c|c|}
\hline $\begin{array}{l}\text { Case } \\
\text { No. }\end{array}$ & $\begin{array}{c}\text { Stature } \\
\mathrm{Cm}\end{array}$ & Age & Cranial & Facial & Mandible & Vertebrae & $\begin{array}{c}\text { Upper } \\
\text { Limb: } \\
\text { R }\end{array}$ & $\begin{array}{l}\text { Upper } \\
\text { Limb: } \\
\text { L }\end{array}$ & Pelvis & $\begin{array}{l}\text { Lower } \\
\text { Limb: } \\
\quad \text { R }\end{array}$ & $\begin{array}{l}\text { Lower } \\
\text { Limb: } \\
\text { L }\end{array}$ \\
\hline $\mathrm{F} 1$ & 147 & 20 & $\mathrm{NI}$ & $\mathrm{NI}$ & $\mathrm{NI}$ & 0 & 0 & 0 & $\mathrm{NI}$ & 2 & 2 \\
\hline F2 & 135 & 14 & $\mathrm{NI}$ & $\mathrm{NI}$ & $\mathrm{NI}$ & 0 & 0 & 0 & Av. & 1 & 3 \\
\hline F3 & $\mathrm{NI}$ & N.A & Av. & $\mathrm{NI}$ & $\mathrm{NI}$ & 4 & 1 & 0 & $\mathrm{NI}$ & 0 & 0 \\
\hline F4 & 152 & 27 & Av. & Av. & Av. & 8 & 2 & 0 & Av. & 3 & 2 \\
\hline F5 & $\mathrm{NI}$ & 14 & Av. & Av. & $\mathrm{NI}$ & 15 & 1 & 1 & $\mathrm{NI}$ & 0 & 0 \\
\hline F6 & 157 & 18 & $\mathrm{NI}$ & $\mathrm{NI}$ & $\mathrm{NI}$ & 3 & 0 & 2 & Av. & 3 & 2 \\
\hline F7 & $\mathrm{NI}$ & N.A & Av. & Av. & Av. & 25 & 3 & 3 & Av. & 1 & 1 \\
\hline F8 & 157 & 19 & Av. & Av. & Av. & 6 & 2 & 3 & $\mathrm{NI}$ & 0 & 0 \\
\hline F9 & 159 & 16 & Av. & Av. & Av. & 6 & 3 & 3 & Av. & 2 & 1 \\
\hline F10 & $\mathrm{NI}$ & 17 & $\mathrm{NI}$ & $\mathrm{NI}$ & $\mathrm{NI}$ & 0 & 1 & 1 & Av. & 1 & 1 \\
\hline F11 & 160 & 16 & $\mathrm{NI}$ & $\mathrm{NI}$ & $\mathrm{NI}$ & 3 & 0 & 0 & Av. & 1 & 1 \\
\hline F12 & 155 & 16 & $\mathrm{NI}$ & $\mathrm{NI}$ & $\mathrm{NI}$ & 0 & 0 & 0 & Av. & 0 & 1 \\
\hline F13 & 160 & 17 & Av. & Av. & $\mathrm{NI}$ & 5 & 1 & 1 & $\mathrm{NI}$ & 0 & 0 \\
\hline F14 & 162 & 17 & $\mathrm{NI}$ & $\mathrm{NI}$ & $\mathrm{NI}$ & 10 & 1 & 0 & Av. & 3 & 0 \\
\hline F15 & $\mathrm{NI}$ & 14 & $\mathrm{NI}$ & $\mathrm{NI}$ & $\mathrm{NI}$ & 0 & 2 & 1 & $\mathrm{NI}$ & 2 & 3 \\
\hline F16 & 157 & N.A & $\mathrm{NI}$ & $\mathrm{NI}$ & $\mathrm{NI}$ & 0 & 0 & 0 & Av. & 0 & 3 \\
\hline F17 & 161 & 16 & $\mathrm{NI}$ & $\mathrm{NI}$ & $\mathrm{NI}$ & 2 & 1 & 2 & Av. & 2 & 1 \\
\hline F18 & 149 & 16 & $\mathrm{NI}$ & $\mathrm{NI}$ & $\mathrm{NI}$ & 3 & 0 & 0 & $\mathrm{NI}$ & 3 & 3 \\
\hline F19 & 144 & 15 & $\mathrm{NI}$ & $\mathrm{NI}$ & $\mathrm{NI}$ & 6 & 1 & 0 & $\mathrm{NI}$ & 0 & 0 \\
\hline $\mathrm{F} 20$ & 161 & 18 & $\mathrm{NI}$ & $\mathrm{NI}$ & $\mathrm{NI}$ & 0 & 0 & 0 & Av. & 2 & 3 \\
\hline $\mathrm{F} 21$ & $\mathrm{NI}$ & 16 & $\mathrm{NI}$ & $\mathrm{NI}$ & $\mathrm{NI}$ & 0 & 0 & 0 & $\mathrm{NI}$ & 0 & 2 \\
\hline $\mathrm{F} 22$ & $\mathrm{NI}$ & N.A & $\mathrm{NI}$ & $\mathrm{NI}$ & $\mathrm{NI}$ & 0 & 0 & 0 & Av. & 0 & 3 \\
\hline F23 & 163 & 18 & $\mathrm{NI}$ & $\mathrm{NI}$ & $\mathrm{NI}$ & 0 & 0 & 0 & Av. & 1 & 3 \\
\hline
\end{tabular}


Figure 2 illustrates the distribution of sex in both sites separately. According to our results, the majority of victims in both sites were females. We reported five females in site 001 among 14 Muslim bodies, while the number of females in site 002 was 14 out of 25 victims. However, we could not determine the sex of seven bodies in site 001 and seven victims in site 002 . The technique applied for age identification was very useful, but the skeletal remains were the challenge for age determination because the victims remaining bones determine the efficacy of the results. ${ }^{11}$ In Figure 3, we explained the distribution of ages in both sites. According to the present study results, most of the victims were young people on both sites. The number of young bodies in site 001 was five bodies, which represent $35.7 \%$ of them all, while 13 out of 25 were young bodies in site 002 , which produced $52 \%$ of all victims.

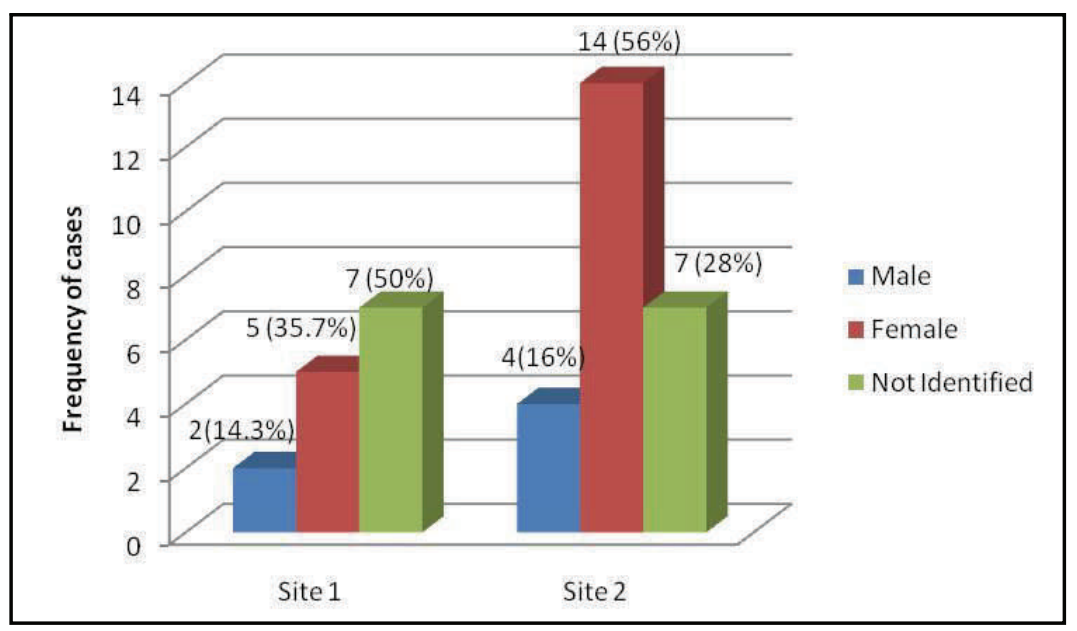

Figure 2: Sex distribution according to sex determination procedure in both sites.

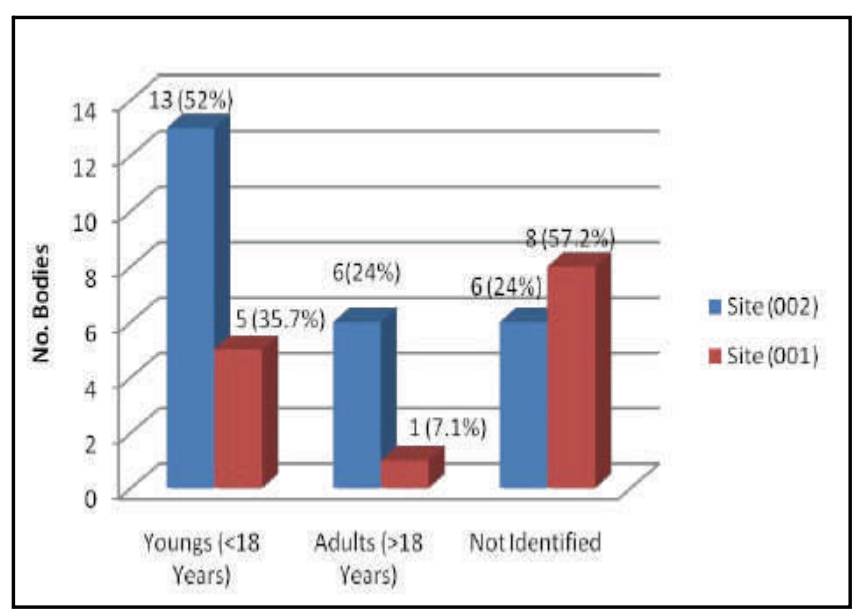

Figure 3: Age distribution according to age determination procedure in both sites.

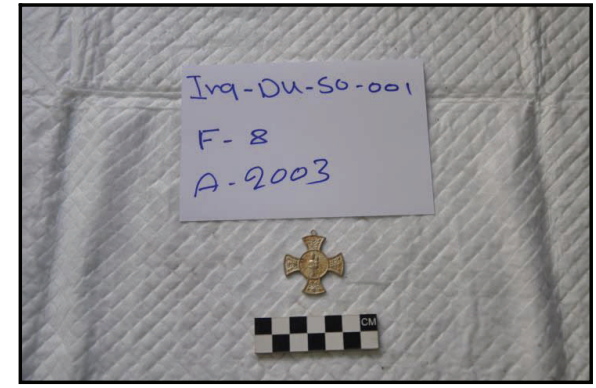

Figure 4: An evidence showing Christian cross found in site 002. 


\section{Discussion}

Before the site determination procedure, we conducted several interviews with the people who lived in that region at that time. For example, we relied on the witness's statements of a mother who claimed that she has two children found in the grave. Also, we took witnesses from the people who were living in the villages around. According to their speech, one of the mass graves contained Christian people with Muslim people after the operation of killing all people (39 persons) of different ages and sex. The victims' families had built a strong and high room around the killed people in the two sites and separated the Christian and Muslim people. The room's dimensions were about 3 by 3 meters and height about 6-7 meters by a strong stone and cement ceiling the room to protect the remain cadaver inside the room. This building room protected for more than 40 years. After we performed the excavation and exhumation works according to the standard procedure, we found the skeletons under $6-7 \mathrm{~m}$ under the ground. There was an accumulation of groundwater that wrapped the bodies, making the works very hard. After ten successive days of working, we finished the works in the field.

\section{Conclusion}

This finding described the exhumation and anthropological evaluation of two mass graves in Sorya, Duhok governorate, the Iraqi Kurdistan region. The majority of the victims were females and contain Christian and Muslim people. Testimonies from relatives and witnesses as well as diverse sources of documentary information. Without the testimonies and witnesses, it was difficult to exhumation and identify and estimate the age and sex in the mass grave of Sorya. Finally, the identification processes of Kurdish mass graves should be supported by funding from the Iraqi and the Kurdistan Regional governments. This will help carry out the work of the mass grave and identify all graves and conduct research to identify mass graves.

\section{Competing interests}

The authors declare no competing interests.

\section{References}

1. Stover E, Haglund WD, Samuels M. Exhumation of mass graves in Iraq: considerations for forensic investigations, humanitarian needs, and the demands of justice. JAMA 2003; 290(5):6636.

2. State UDo. Iraq human rights report. In. USA: US State Government; 2015.

3. Groen WM, Márquez-Grant $\mathrm{N}$, Janaway $\mathrm{R}$. Forensic archaeology: a global perspective: John Wiley \& Sons; 2015

4. Khogir W, Linda F. The Christians Perceptions of Reconciliation and Conflict. Middle East Research Institute 2017: 5.

5. "Iraqi Christians' long history". BBC. 13 March 2008. (Accessed October 31, 2010, at https://www.bbc.com/news/world-middle-east11669994).

6. Juhl K. The contribution by (forensic) archaeologists to human rights investigations of mass graves: Museum of archaeology, Stavanger, Norway; 2005.

7. McKinley Jl. Compiling a skeletal inventory: cremated human bone. Updated Guidelines to the Standards for Recording Human Remains 2004:14

8. Cox M. Ageing adults from the skeleton. Human osteology in archaeology and forensic science. Cambridge, UK: Cambridge University Press; 2000. P. 61-82.

9. Mays S. Sex determination in skeletal remains. Human Osteology in Archeology and Forensic Science. Cambridge, UK: Cambridge University Press; 2000. P. 117-30.

10. De Mendonca M. Estimation of height from the length of long bones in a Portuguese adult population. American Journal of Physical Anthropology: The Official Publication of the American Association of Physical Anthropologists 2000; 112(1):39-48.

11. Komar DA, Buikstra JE. Forensic anthropology: contemporary theory and practice. New York: Oxford university press; 2008. 